advances. Fundamental research is more a function of the universities. There is still much to be done in extending scientific academic facilities, and while this is a great opportunity for Government assistance, industry has also a big part to play, and he pleaded that industry should assist by financial grants. Lord Brabazon warmly applauded the work of scientific men in Great Britain. He also referred to the need for scientific men who could bring together and correlate the knowledge of different branches of science.

The debate was resumed on July 20 , and Lord Cherwell, replying for the Government, reviewed the question of Government intervention in research. Admitting that in the last decade emphasis had tended rather away from fundamental research to the industrial side, he said that the whole distribution of effort is now being reviewed, and he hoped that it would be agreed to extend considerably Government support of pure scientific research. It is extremely difficult to make people realize the importance of fundamental scientific research and its value to the community, but even from the economic point of view we cannot overrate the importance of fostering such research. While that must be in large measure the responsibility of the Government and carried out at the universities, the Government also wishes to encourage industry to spend money on pure research. It is the policy and intention of the Government to increase the assistance given to pure research, but any similar developments in industry would be welcomed. Lord Cherwell welcomed a reference made to training in science, and said that the Board of Education is conscious much remains to be done in this field and is anxious to develop it as part of its policy for post-war reconstruction. Frankly admitting that the Civil Service has not hitherto shown due regard for the contribution which men of science are making to the nation's welfare, he stated that an investigation has been in progress to make sure that the conditions of service, pay and prospects of Government scientific employees compare favourably with those on the administrative side so that, among other things, interchange might be made easier, and he hoped that a definite announcement that these reforms are to be put into effect would be made before long. In welcoming this statement, Lord Winster expressed the view that when the history of Mr. Churchill's administration came to be written, it would contain a chapter on what has been done for the encouragement of science in Government Departments that would reflect the greatest credit on the Prime Minister.

\section{A Pioneer of the Rubber Industry}

ON July 25 occurred the centenary of the death of the Scottish chemist Charles Macintosh, whose name is now a household word through his discovery of how to render cloth waterproof by cementing two layers of fabric together with a solution of rubber in naphtha. His patent for the process was taken out in June 1823, and at the works he established at Manchester the first "Waterproof Double Textures" were manufactured. His work was contemporary with that of Thomas Hancock (1786-1865), who for many years was his collaborator and partner. Together they firmly established the rubber industry in Great Britain. To Hancock also belongs the credit for the introduction of the 'vulcanization' of rubber, but he was led to the discovery of this process through experiments made after receiving a piece of rubber which had been subject to the process of 'solarization' by Charles Goodyear (1800-60) in America.

Macintosh was the son of a practical chemist and was born in Glasgow on December 29, 1766. As a youth he attended the lectures of Black at Edinburgh, and at the age of twenty began manufacturing sal ammoniac. He started the first alum works in Scotland, and for a time was associated with Charles Tennant of the St. Rollox works in Glasgow. He travelled a good deal on the Continent and was known to most of the principal chemists of his day. Among his friends was James Beaumont Neilson, F.R.S., the first engineer of the Glasgow gas works and the in. ventor of the 'hot blast'. In 1819 Macintosh engaged to take all the tar and ammoniacal liquor-then waste products-from the gas works, and it was in his treatment of the tar that he obtained naphtha, which he found could be used to make waterproof varnishes.

\section{Royal Society of Edinburgh: Robert Cormack Bequest}

ThF Royal Society of Edinburgh has been made the residuary legatee of the estate of Mr. Robert Cormack, of Edinburgh, who died on August 13, 1942. The Society is directed to administer this bequest for the purpose of promoting astronomical knowledge and research in Scotland, so far as practicable, on the lines of a memorandum prepared in 1931 by the late Prof. R. A. Sampson, Astronomer Royal for Scotland. The Council, on behalf of the Royal Society of Edinburgh, has accepted the bequest, which represents an amount somewhat over $£ 30,000$; and, after careful consideration, has approved a general scheme for the administration of the Trust, which will include: $(a)$ research fellowships to be awarded on suitable conditions to students engaged on research in Scottish observatories and to students or graduates of Scottish universities desirous of engaging in research in foreign or Dominion observatories; (b) the publication of the results of such research; (c) lectures to be delivered in suitable centres by eminent foreign or Dominion astronomers ; (d) grants in aid of the purchase of special equipment for use in Scottish universities or observatories in research work; $(e)$ lectures and demonstrations of a more popular character under the auspices of the Scottish educational institutions. A large part of this scheme will not be developed during the War.

\section{Fleas of North America}

UNDER the foregoing title, H. E. Ewing and Irvine Fox have written a taxonomic revision of the North American Siphonaptera. Such diseases as bubonic plague and a mild form of typhus are carried to man by the agency of these insects, which also play an important part as pests of livestock, etc. The matter of correctly identifying fleas assumes, therefore, considerable importance, and the present work will aid those engaged in such procedure. Full descriptions are given of the genera and higher groups, and are accompanied, for the most part, by illustrations of diagnostic characters. Formal descriptions of species and subspecies are avoided and, instead, remarks on characteristic features are given. The paper is issued as Miscellaneous Publica. tion No. 500 of the U.S. Department of Agriculture 